\title{
HOPE IN BUSINESS ORGANIZING FOR SOCIETAL PROGRESS: \\ THREE NARRATIVES ${ }^{1}$
}

\author{
Stewart Clegg \\ UTS Business School \\ University of Technology Sydney (UTS) \\ and \\ Nova School of Business and Economics \\ Universidade Nova de Lisboa \\ s.clegg@uts.edu.au \\ Ace Volkmann Simpson \\ UTS Business School \\ University of Technology Sydney (UTS) \\ ace.simpson@uts.edu.au \\ Miguel Pina e Cunha \\ Fundação Amélia de Mello Professor of Leadership \\ Nova School of Business and Economics \\ Universidade Nova de Lisboa \\ mpc@novasbe.pt
}

\section{Arménio Rego}

Católica Porto Business School, Universidade Católica Portuguesa, Portugal

and

Instituto Universitário de Lisboa (ISCTE-IUL), Business Research Unit, Lisboa, Portugal arego@porto.ucp.pt

${ }^{1}$ Part of this chapter is adapted from chapter 11 of Positive Organizational Behavior (Routledge, 2019) 


\section{INTRODUCTION}

This chapter explores the role of capitalist organizations in providing hope for the betterment of society. At the individual level Snyder has defined hope, "as the perceived capability to derive pathways to desired goals, and motivate oneself via agency thinking to use those pathways" (Snyder 2002, p. 249). Yet we are concerned with hope at the broader societal level. Accordingly, we draw upon Braithwaite's (2004) sociological definition of collective hope as "a shared desire for a better society, articulated through a broad set of agreed-upon goals and principles, developed and elaborated through socially inclusive dialogue" (p. 146). The impact of business organizations on social and other relations are significant. Capitalistic organizations have a fundamental role in the betterment of society through the widely agreed upon objectives of fostering of prosperity, wealth creation and innovation. Unfortunately, they also tend to breach their social licence by additionally fostering exploitation, degradation and domination. Our emphasis is nonetheless hopeful, concerned with questioning the conditions under which business organizations contribute towards social wellbeing? Towards this end, as we summarize in Table 1, we organize the material using a framework with three areas of analysis or narratives: (1) ethical (2) empirical, and (3) prudential (Riemer, Simon, \& Romance, 2013).

\section{Table 1. Three narratives}




\begin{tabular}{llll}
\hline Narrative & Basis & Question & Discipline \\
\hline Ethical & Values & What ought to be? & Philosophy \\
Empirical & Facts & What is? & Science \\
Prudential & Judgement & What can be? & Policy \\
\hline
\end{tabular}

Our ethical analysis is concerned with the question: "what ought to be?" The focus here is on values, with philosophy as the foundation. This domain is normative in prescribing, within the context of this chapter, that business activity ought to promote social wellbeing. Our review of the literature will touch on more than two thousand years of western thought on wealth generation, from the classical Greek philosopher Socrates, to the medieval Church, to the philosophers of the enlightenment. This broad philosophical review will introduce us to some of the most influential thinking that has formed the foundational bedrock of western civilization through the ages to the current day.

An empirical analysis provides a descriptive understanding of the relationship between business activity and society, focusing on the question: "what is?" Here we are draw on scientific observation as our foundation in considering economic data collected over centuries. The analysis will demonstrate that the organization of business activity has both positive and negative social effects both inspiring and discouraging hope. If the question is how to promote social betterment while inhibiting social harm we conclude that this is always a matter of judgement.

The prudential analysis will therefore consider how judgement influences the contingencies whereby business organizations can generate profits while reducing social harm and fostering social betterment (or not). Our primary question here is: "what can be?" We address this question by considering the role of policy and values in informing 
capitalist organizational practices that have a goal of contributing to the good of society. We analyse practical pathways organizations can take and are taking to be a force for good in the world using models such as corporate social responsibility, creating shared value, stakeholder theory, conscious capitalism and sustainability. While considering these different models, we will also reflect on their limitations - which leads us to conclude by reflecting on the vital role of democratic governance of society; more radically we consider the design of organizations around inclusive, participatory democratic values as a safeguard of hope.

\section{THE ETHICAL NARRATIVE}

A widely held assumption of our time is that business organizations drive societal progress by creating jobs, products and services and investment in innovative technologies that solve human problems. This is a relatively recent view, emerging in the 17 and $18^{\text {th }}$ centuries with the twin innovations of the Enlightenment and the advent of industrial capitalism and best captured by Adam Smith (1776) in An Inquiry into the Nature and Causes of the Wealth of Nations. New social constructions emerged as an unanticipated result of ultimate ethical and religious values (Weber, 1930) that kick-

started the process that Smith referred to as "primitive accumulation". Calvinism generated not only a work ethic but also, in consequence, capital. We can gain insight into this social construction by contrasting it with past constructions.

Through much of history, philosophers, Church leaders and rulers were less than hopeful of the social benefits of commerce, viewing the merchant and business activity as socially subordinate if not malignant. Aristotle distrusted merchants. He emphasized a 
state governed by a virtuous middle class of free men (women were not included) heading self-sufficient households, where independent craftsmen or slaves deemed unworthy of citizenship, provide material needs. The possession of sufficient wealth was necessary for civic engagement (voting in the agora and military duty to defend the city) and the excise of virtuous liberality and magnanimity in sacrificing for the common good. The active pursuit of wealth through trade was regarded as morally hazardous - "the trafficking in goods" through commerce where wealth is the means and objective of exchange was viewed not only as counter to political virtue but also individual moral wellbeing: "the citizens should not live a vulgar... or a merchant's way of life", he wrote, "for this sort of way of life is ignoble and contrary to virtue" (Aristotle, 2013, p. 202). Athenian bankers, merchants and moneylenders were even denied citizenship (Millett, 2002).

The Christian Gospels and early Church Fathers were similarly suspicious and even hostile towards merchants and trade. According to the Apostle Mark, Jesus drove out all of those "that sold and bought in the temple", as he "overthrew the tables of the moneychangers, and the seats of them that sold doves" (Mark 12:15-16, The Bible: Authorized King James version, 1997). Apostle Matthew reports that in his Sermon on the Mount, Jesus preached "For where your treasure is, there will your heart be also", "Ye cannot serve God and mammon" (Mathew 6:21-24, The Bible: Authorized King James version, 1997). The Decretum, a collection of canon law from the middle of the twelfth century, referenced these passages declaring: "The man who buys in order that he may gain by selling it again unchanged as he bought it, that man is of the buyers and sellers who are cast forth from God's temple" (Cited in Tawney, 1926, p. 35). 
In the late middle ages, a more urban economy arose with the development of cities and new financial instruments as the bonds of feudalism were increasingly weakened by peasant revolt, bubonic plague and pestilence, the latter caused by calorific shortfalls because of the exhaustion of available land using the available technology in the face of diminishing yields for an increasing population (Anderson, 1974). The Scholastic theologians headed by Thomas Aquinas presented a more hopeful reconsidered Church position on commerce, one that reconciled the Church with the views of the texts of the newly rediscovered Aristotle (Muller, 2003). Private property was held to be legitimate as it was the basis for the family and social order, where division of labour "naturally" led to the hierarchy of estates (status groups). Economic activity was necessary for a family head to support their dependents appropriate to the standards of their estate.

Through a rhetorical process of paradiastole, enlightenment philosophers redistributed virtues and vices and vice versa (Skinner, 1996). Mandeville's (1670-1733) The Fable of the Beas, or Private Vices, Public Benefits, which was published in 1723, makes the case that individual self-interested character dispositions of pride, vanity and ambition, long stigmatized as vices, were in fact necessary conditions for social prosperity. Mandeville's insistence that economic prosperity would cease without individual ambition for luxury and pride was echoed in the century that followed both by proponents such as Voltaire and Adam Smith and critics such as Karl Marx. The latter agreed with Mandeville's analysis of the vicious basis for commerce but did not share his admiration for the private accumulation of affluence (Muller, 2003). Adam Smith (1723-1790) developed arguments supporting individual self-interest as the basis for social order in An inquiry into the nature and causes of the wealth of nations (Smith, 1776). Smith reasoned that 
a liberal capitalist market economy, where people have the freedom to compete in pursuing their own self-interest, is the best vehicle for improving the standard of living of the greatest majority of the population, leading to what Smith termed "universal opulence".

Smith was well aware of the need for a moral order as well (Smith, 2010). Smith's "commercial society" was referred to pejoratively by Marx (1818-1883), its critic, as "capitalism" (Marx, 2015), a term now embraced positively even by the market's fiercest advocates. Marx saw market competition as inherently a morally abhorrent system of exploitation, inequality and political instability that systematically alienated skilled workers from the products they produce. The effect was to turn artisans into paid labourers, doing routine tasks in assembly lines "as living appendages" of the machines they operated.

The above historical overview of Western thought is ambivalent in providing hope concerning the relationship between the organization of wealth generation and the betterment of society, but also mostly theoretical. What does the empirical evidence tell us about the relationship between organizations, specifically financial organizations, and social wellbeing? Is there support for Voltaire and Adam Smith's arguments that trade provides a common platform for inclusive dialogue supporting peace and prosperity among trading nations?

\section{THE EMPIRICAL NARRATIVE}

While Voltaire regarded the London Stock Exchange as the embodiment of how trade achieves the objective of international collaboration and peace, there is evidence of 
business organizations contributing to violent social conflict through collusion with authoritarian state authorities, through assuming the role of government, and through various forms of human rights abuse or neglect of people's working conditions (Banerjee, 2008; Reinecke \& Donaghey, 2015).

The part played by the British East India Company, described as one of the world's first multinational organizations (Clegg, 2016), in expanding the British Empire as one based on commerce, provides one such negative example. With the support of its private army, the Company came to rule most of India. Tax revenue eventually eclipsed profits from trade as the greater source of shareholder dividends (Robins, 2007). The British South Africa Company similarly employed a private military that was engaged in capturing African diamond mines, furthering the interests of both the firm and the British state (Thomas, 1996).

It may be objected that these examples of profit-seeking organizations colluding with state authorities in undermining the security and rights of sovereign populations are confined to a past historical era of colonialism. There are, however, numerous cases that are more recent. Doing business with dictatorial regimes, as transpired with IBM maintaining computational machines used in the Nazi concentration camps during WWII (Wilson, 1993) is one high profile example. Ikea's collusion with the oppressive Communist East German Government by contracting prison labours in the 70 s and 80 s to manufacture its furniture (Connolly, 2012) is another case. Shell has also been criticized in the 1990s for collusion with dictatorial regimes and complicity in human rights abuses associated with its Nigerian subsidiary and the Government of Nigeria (Wheeler, Fabig, \& Boele, 2002). Despite millions of dollars of royalties being generated, 
local communities affected by company operations remained hopelessly impoverished as traditional livelihoods were eroded.

It is increasingly typical for multinational mining companies operating in developing countries to employ transnational private armies to protect their interests from violent conflicts that arise between indigenous communities, governments and the multinational organizations (Mbembe, 2008). Banerjee describes such destructive business practices that involve dispossession, infra-human working conditions, and even death as necrocapitalism, defined as "contemporary forms of organizational accumulation that involve dispossession and the subjugation of life to the power of death" (Banerjee, 2008, p. 1541).

There are, however, more hopeful alternative examples of business organizations operating in a manner that promotes social wellbeing in terms of security, peace and prosperity (Kanter, 2011, p. 2, wrote about how "great companies (...) instead of being mere money-generating machines, (...) combine financial and social logic to build enduring success"). Economists note that with the arrival of capitalistic business organizations, economic growth, as measured by gross domestic product (GDP), has triggered a significant rise in the world's wealth. The world's economy was stagnant for 820 years from the year 1000 up until 1820, during which it grew just six-fold (Wolf, 2004). With the arrival of capitalism and the industrial revolution, in the 178 year period between 1820 to 1998 , the world economy grew 50-fold, at a rate faster than population growth, with an average nine-fold increase in individual incomes. More important for the objective of enhanced social wellbeing, these GDP increases translated into improved standard of living with increased availability of food, clothing, shelter and 
health care (Easterlin \& Angelescu, 2012) and decreases in average weekly working hours and work by children and the elderly (Barro, 1997).

Can business organizations contribute to peace? This is the question Spreitzer (2007) sought to answer empirically in a novel manner - using cross-country data from existing international databases. Spreitzer found that in countries where the leadership of business organizations is more participative and where employees have greater agency and decision-making authority, there is significantly less corruption and unrest. The causation of this association can, of course, flow in the opposite direction, where more democratic countries lead to more participatory business organizations.

\section{THE PRUDENTIAL NARRATIVE}

Having completed a review of ambivalent ethical prescriptions for the relationship between business organizations and society, as well as mixed empirical evidence describing positive and negative effects of this relationship, we now consider the prudential implications of managerial judgment in fostering potential social benefits and minimizing negative effects. It is here, more than anywhere else, that one can identify cause for hope. Braithwaite (2004, p. 146) holds that the process of collective hope requires for three elements to work in concert: "commitment to shared goals, collective efficacy through democratic participation and a sense of group membership, and trust in institutional pathways for implementation". Management is often taught as a valueneutral science based purely upon the objective reading of factual data (Ghoshal, 2005) but the centrality goals and agency means that managing is always interpreted through 
the filter of values. Every decision incorporates values based upon deeper philosophical assumptions: some values strive for narrow benefit; others strive wider.

Corporate Social Responsibility (CSR) conveys the notion of business organizations selfregulating through the voluntary uptake of socially responsible practices above and beyond what is required by the letter of the law as a demonstration of corporate citizenship or corporate conscience (Ghoshal, 2005). Organizations that act, as would any good citizen, in a fair and responsible manner, doing the right thing by others, are admired more than rapacious counterparts. For some, however, the ideas of Voltaire and Smith about self-interest providing a social benefit are taken to the extreme in arguing that the sole responsibility of business is to maximise profits for shareholders (Friedman, 1970). In contrast, there is increasing recognition that it is essential for organizations to operate in a socially responsible matter beyond what is required of the law, as many legal activities are socially reprehensible.

Key practices for implementing CSR within business organizations include appointing directors or managers responsible for CSR, developing and publicizing CSR statements and ethical codes of practice, donating to charities and supporting social and environmental causes, enrolling as a member of public forms or environmental groups and publicizing a record of socially responsible practices. Claims of CSR practices made by organizations, however, are not necessarily legitimate. Organizations are often accused of adopting CSR merely to engender public and shareholder trust and reduce legal risk, as a cynical public relations exercise in "window-dressing" designed to preempt the government's role as social watch-dog (Henderson, 2001). Business organizations also sometimes use CSR to deflect public attention away from harmful 
aspects of their business practices. Cynicism towards CSR, both by business executives and critics, places business organizations in an absurd situation where they are damned if they ignore the negative social impacts of organizational operations but also criticized for trying to do something about it (Morsing, Schultz, \& Nielsen, 2008). At the end of the day, it is better to be damned for trying to do what is right than for acting as a "social parasite" (Hanlon \& Fleming, 2009, p. 944).

Creating shared value (CSV) is a concept which builds upon the notion of CSR introduced by Porter and Kramer (2006). These authors challenge the idea that the activities of business organizations and the wellbeing of society necessarily conflict with each other. Rather, they argue, the success of both business and the community are mutually interdependent. Business organizations therefore should identify and enact policy that leverages the natural links between their strategies and CSR, by shifting their focus away from responsibilities, towards a focus on value creation. They portray CSR as often reactionary and driven by external pressures, reputation management and constrained by budgetary limitations. The interests of society are pitted against the interests of the business organization, highlighting the costs of complying with externally enforced social requirements. CSV in contrast is proactive and driven internally by strategic opportunities that provide benefit both for the organization and society. Here the focus is on opportunities for competitive advantage through incorporation of a social value proposition within the organizational strategy. CSV represents a significant shift in paradigm from the traditional role of how business organizations see their role in society, as well as themselves. 
Stakeholder theory is another approach that seeks to address the limitations of CSR. Stakeholder theory argues that the numerous groups impacted by organizational practices have a legitimate voice that needs to be acknowledged in organizational policy and decision-making. Originally articulated by Freeman (1984), stakeholder theory defines a stakeholder as "any group or individual who can affect or is affected by the achievement of the organization's objectives" (p. 46). As further developed by Mackey and Sisodia (2013), conscious capitalism has become a worldwide movement. These authors argue that capitalism correctly practiced has essential qualities of goodness, ethicality, nobility and heroism. Its goodness springs from its ability to create value for stakeholders; its ethicality rests on its foundation of free voluntary exchange; while its noble heroism derives from the power to alleviate human poverty and drive economic prosperity.

Sustainability scholars emphasize the interactional relations between the environment and socio-economic activity. Hence the trifurcation of social, environmental and economic considerations, sometimes usually qualified as "the 3 Ps" (people, planet, profit). The pathways of CSR, CSV and stakeholder orientations through which business organizations demonstrate "commitment to shared goals...and a sense of group membership" (Braithwaite 2004, p. 146) in contributing towards the public good provides a source of collective hope. Nonetheless, we see the need for one more piece in this puzzle: the safeguarding of these pathways through "democratic participation...and trust in institutional pathways for implementation" (Braithwaite 2004, p. 146). 
The best antidote to unscrupulous behaviour and safeguarding the public good is democracy, both societal and organizational. For much of the twentieth century, especially in Scandinavia, the dominant feature in organization design was the implementation of the principles of industrial democracy. Scandinavian industrial democracy was partly based on socio-technic systems theory, which began in the London-based Tavistock Institute in the post war period but had its most notable takeup in Scandinavia, initially in Norway (Klemsdal, Ravn, Amble, \& Finne, 2017). Sociotechnical systems theory saw self-organizing teams defining their own work as the core element of organizational design, humanizing work in the process, away from the mechanism of other approaches such as Taylorism and bureaucracy (Battilana, Fuerstein, \& Lee, 2017; Lee \& Edmondson, 2017). The focus was on how people and technology could interact productively and in an empowering way. These concerns became widely espoused in Scandinavia, even becoming embedded as part of the founding principles of the tripartite union/business/government Arbetslivscentrum, Centre for Working Life, in Sweden, sponsoring policy innovations to improve the quality of working life.

North American management thinking, which, because of the power of its numbers, dominates global English-language discussions, has long spurned notions of industrial and organizational democracy. There are, however, longstanding European traditions of organizational democracy in Scandinavia, of works councils in the Netherlands, Germany and Austria which, with their traditions of participatory codetermination, have only been lightly discussed, if at all, in the dominant English-speaking management literature of recent years (Balfour, 2018; Lecher, Platzer, \& Weiner, 2018; Sorge, 2018). If 
management's right to manage through the domination of their perspectives and the authority of their positions is assumed as a taken-for-granted feature of the Englishspeaking world, there is considerably more mutuality and joint decision-making between managers and employees in these European approaches. In addition, there are deep-rooted traditions of cooperative design and management evident in many sectors of the global economy, especially in producer cooperatives, discussion of which is largely neglected in the literature.

One provocative defence of democracy is provided by Tonkinwise (2018) who stresses that the definition of who is an organizational stakeholder needs expending to include marginalized peoples, by race, class or ability, as well as a wide range of non-users, people from across the whole-of-life supply chain and delegates representing future generations and non-human actors. Together with this expanded notion of democracy, organizations should, it is suggested, be engaged in advocacy of visions for the future that the organization is working toward and prepared to evaluate its work against as well as advocating participation in the profits from design for all involved - from makers and maintainers to users and end of life disposers and recyclers. It is a profound and radical view of organizational democracy as a key component of a fully societal democracy, serving as a safeguard of the public good, a view that inspires us with hope.

\section{CONCLUSION}

We see hope in business organizations consciously embracing the goal of functioning as a force for social wellbeing. It would be impossible and undesirable for government to oversee the operations of all business organizations to the extent of forcing all 
businesses to embrace the mission of being a force for good. Democratic government does have a responsibility, however, to ensure that organizations do not cause harm. History has demonstrated the totalitarian oppression that ensures from governments that adopt ideologically authoritarian assumptions. There are many variants of these expressed in the philosophies discussed in our ethical narrative which, depending on their proclivities, will label specific forms and design of business activity as, a priori, either negative or positive.

On the contrary, as is demonstrated in our empirical narrative, a more nuanced position is that the impact of business activities on society may be positive or harmful. It is a matter of strategic choice, as we emphasize in our prudential narrative. We find hope in evidence of an emerging counter-movement seeking to reign in corporate capitalism and consciously consider the needs of a broader group of stakeholders. The explicit inclusion of hope in the vocabulary of positive organizational scholarship is another indication that the notion of hope should be embraced by organizations as a collective project (Cunha, Rego, Simpson \& Clegg, 2019), emphasizing attention no only to present goals but also to future aspirations and impacts.

The more organizational voices that are democratically invited to contribute to designing and stewarding the processes of organizational governance at not just societal but also organizational levels, the more we hold hope in the possibility that business might be organizing for societal progress as well as profit. 


\section{REFERENCES}

Aristotle. (2013). Aristotle's Politics (C. Lord, Trans. 2nd Ed.). Chicago: University of Chicago Press.

Balfour, C. (2018). Workers' Participation in Western Europe Participation in Industry (pp. 181-212). London: Routledge.

Banerjee, S. B. (2008). Necrocapitalism. Organization studies, 29(12), 1541-1563.

Barro, R. (1997). Macroeconomics. Cambridge and London: MIT Press.

Battilana, J., Fuerstein, M., \& Lee, M. (2017). New prospects for organizational democracy? How the joint pursuit of social and financial goals challenges traditional organizational designs. In R. Subramanian (Ed.), Capitalism Beyond Mutuality. Oxford: Oxford University Press.

The Bible: Authorized King James version. (1997). (R. Carroll \& S. Prickett Eds.). Oxford: Oxford University Press..

Bower, J. L. \& Paine, L. S. (2017). The error at the heart of corporate leadership. Harvard Business Review, May-June, 50-60.

Braithwaite, V. (2004). Collective hope. The Annals of the American Academy of Political and Social Science, 592(1), 6-15.

Cebon, P., \& Hermalin, B. E. (2015). When less is more: The benefits of limits on executive pay. Review of Financial Studies, 28(6), 1667-1700. 
Clegg, S. (2016). The East India Company: the first modern multinational. In C. Dörrenbächer \& M. Geppert (Eds.), Multinational corporations and organization theory: Post millennium perspectives. Bingley: Emerald.

Connolly, K. (2012). Ikea says sorry to East German political prisoners forced to make its furniture. The Guardian, 17 November. Retrieved from http://www.theguardian.com/business/2012/nov/16/ikea-regrets-forcedlabour-germany

Cunha, M.P., Rego, A., Simpson, A.V. \& Clegg, S. (2019). Positive organizational behavior. London: Routledge.

Dalton, D. R., Daily, C. M., Ellstrand, A. E., \& Johnson, J. L. (1998). Meta-analytic reviews of board composition, leadership structure, and financial performance. Strategic Management Journal, 19(3), 269-290.

Easterlin, R. A., \& Angelescu, L. (2012). Modern economic growth and quality of life: cross-Sectional and time series evidence. In K. C. Land, A. C. Michalos, \& M. J. Sirgy (Eds.), Handbook of social indicators and quality of life research (pp. 113136). London: Springer.

Freeman, R. E. (1984). Strategic management: A stakeholder approach. London: Pitman.

Friedman, M. (1970). The social responsibility of business is to increase its profits. The New York Times, September 13, SM12.

Ghoshal, S. (2005). Bad management theories are destroying good management practices. Academy of Management Learning \& Education, 4(1), 75-91. 
Hanlon, G., \& Fleming, P. P. (2009). Updating the critical perspective on corporate social responsibility. Sociology Compass, 3(6), 937-948.

Henderson, D. (2001). Misguided virtue: False notions of corporate social responsibility: New Zealand Business Roundtable.

Kanter, R. M. (2011). How great companies think differently. Harvard Business Review, 89(11), 66-78.

Klemsdal, L., Ravn, J. E., Amble, N., \& Finne, H. (2017). The organization theories of the industrial democracy experiments meet contemporary organizational realities. Nordic Journal of Working Life Studies, 7(S2), 1-15.

Lecher, W., Platzer, H. W., \& Weiner, K. P. (2018). European Works Councils: development, types and networking. London: Routledge.

Lee, M. Y., \& Edmondson, A. C. (2017). Self-managing organizations: Exploring the limits of less-hierarchical organizing. Research in Organizational Behavior, 37, 35-58.

Mackey, J., \& Sisodia, R. S. (2013). Conscious capitalism: Liberating the heroic spirit of business. Boston, MA: Harvard Business Press.

Marx, K. (2015). Das kapital. Sydney: Media Galaxy.

Mbembe, A. (2008). Necropolitics. In S. Morton \& S. Bygrave (Eds.), Foucault in an Age of Terror (pp. 152-182). London: Palgrave Macmillan.

Millett, P. (2002). Lending and borrowing in ancient Athens. Cambridge: Cambridge University Press. 
Morsing, M., Schultz, M., \& Nielsen, K. U. (2008). The 'Catch 22' of communicating CSR: Findings from a Danish study. Journal of Marketing Communications, 14(2), 97111.

Muller, J. Z. (2003). The mind and the market: capitalism in Western thought. New York: Anchor.

Pfeffer, J. (2010). Building sustainable organizations: The human factor. The Academy of Management Perspectives, 24(1), 34-45.

Porter, M. E., \& Kramer, M. R. (2006). Strategy \& Society. The link between competitive advantage and corporate social responsibility. Harvard Business Review, 84(12), 78-92.

Reinecke, J., \& Donaghey, J. (2015). After Rana Plaza: Building coalitional power for labour rights between unions and (consumption-based) social movement organisations. Organization, 22(5), 720-740.

Riemer, N., Simon, D. W., \& Romance, J. (2013). Challenge of Politics. Washington, DC: Sage.

Robins, N. (2007). This imperious company. Journal of Corporate Citizenship, 27, 31-42.

Skinner, Q. (1996). Reason and rhetoric in the philosophy of Hobbes. Cambridge: Cambridge University Press.

Smith, A. (1776). An inquiry into the nature and causes of the wealth of nations. London: Cass. 
Smith, A. (2010). The theory of moral sentiments. New York: Penguin.

Snyder, C.R., 2002. Hope theory: Rainbows in the mind. Psychological Inquiry, 13(4), 249-275.

Snyder, C. R., Irving, L., \& Anderson, J. R. (1991). Hope and health: Measuring the will and the ways. In C. R. Snyder \& D. R. Forsyth (Eds.), Handbook of social and clinical psychology: The health perspective (pp. 285-305). Elmsford, NY: Pergamon.

Spreitzer, G. (2007). Giving peace a chance: Organizational leadership, empowerment, and peace. Journal of Organizational Behavior, 28(8), 1077-1095.

Tawney, R. H. (1926). Religion and the Rise of Capitalism. New Brunswick: Transaction.

Thomas, A. (1996). Rhodes: The Race for Africa. New York: St Martin's Press.

Tonkinwise, C. (2018). This Time, It is really Happening: Democracy must be Defended, by Undemocratic Design Specifications. Available at www.academia.edu/download/55656731/De-Democracy II.pdf

Weber, M. (1930). The Protestant ethic and the spirit of capitalism and other writings (T. Parsons, Trans.). London: Routledge.

Wheeler, D., Fabig, H., \& Boele, R. (2002). Paradoxes and dilemmas for stakeholder responsive firms in the extractive sector: Lessons from the case of Shell and the Ogoni. Journal of Business Ethics, 39(3), 297-318. 
Wilson, S. (1993). Historicism. The Year's Work in Critical and Cultural Theory, 3(1), 164189.

Wolf, M. (2004). Why globalization works. New Haven: Yale University Press. 
